\title{
Circle of Fear in Early China
}

\author{
Michael Nylan * and Trenton Wilson
}

\section{check for}

updates

Citation: Nylan, Michael, and Trenton Wilson. 2021. Circle of Fear in Early China. Religions 12: 26 https://doi.org/10.3390/rel12010026

Received: 6 November 2020 Accepted: 22 December 2020 Published: 31 December 2020

Publisher's Note: MDPI stays neutral with regard to jurisdictional clai$\mathrm{ms}$ in published maps and institutional affiliations.

Copyright: $(\odot 2020$ by the authors. Licensee MDPI, Basel, Switzerland. This article is an open access article distributed under the terms and conditions of the Creative Commons Attribution (CC BY) license (https:// creativecommons.org/licenses/by/ $4.0 /)$.
Department of History, University of California-Berkeley, Berkeley, CA 94720, USA; trenton.wilson@berkeley.edu * Correspondence: mnylan@berkeley.edu

\begin{abstract}
Montesquieu wrote that "China is a despotic state whose principle is fear". And indeed, in the early modern context in China, fear and despotism, on the one hand, were opposed to ziyou 自 由 ("freedom"), on the other. These constructs created a discursive space in which theorists of the nation-state felt the need to articulate the complex relations binding despotism to fear. By contrast, during the early empires in China a different set of relations was imagined, wherein salutary fear was aligned against both despotism and freedom and, crucially, with according others a proper sense of dignity. For by the arguments of remote antiquity, "submission to instruction and fear of the gods" functioned both as a vital check on despotism and as the key barrier to the unchecked and unhampered self-assertion by subjects and rulers. Yet this notion of ritual operating within a circle of fear it helped to foster has so far escaped scholarly notice, perhaps because it does not square with the ritual theories that dominate our modern discourse and perhaps because such ritual fear has been dismissed easily as remnant, primitive superstition.
\end{abstract}

Keywords: ritual theories; fear; classical China; autocratic rule; freedom

"It's hard to believe that people's fear of offending is greater than their fear of pain, but it is". -Girl with the Dragon Tattoo, said by the arch-villain

Montesquieu wrote that "China is a despotic state whose principle is fear". ${ }^{1}$ Shortly after the Wuchang uprising that led to the toppling of the Qing dynasty in 1911, a Qing official stationed in Gansu sent a telegram to General Yuan Shikai 袁世凱 (1859-1916), pleading with him to establish a constitutional monarchy rather than a republican form of government. The official, drawing directly or unwittingly on Montesquieu, wrote, "For four thousand years, our people of the central plains have been nourished by despotism. Submission to instruction and fear of the gods has long since become habit". ${ }^{2}$ Another Qing official, seeming to lodge much the same argument, made a far more interesting and complex statement, "It is not that we do not know about the need to escape despotism and respect freedom ... It is rather that true independence cannot be established without monarchic rule". ${ }^{3}$ In this early modernizing context, fear and despotism, on the one hand, were opposed to ziyou 自由 ("freedom"), and yet the two remain somehow intertwined. As the modern scholar Hou Xudong 侯旭東 and other scholars have indicated, these concepts created a discursive space in which even many of those who defended the "despotic" Qing state or its later successor states in China were forced to consider the complex relations binding despotism and fear. ${ }^{4}$ Our prime contention here, however, is that in remote antiquity, during the early empires, salutary fear was aligned against both despotism and the word that later came to mean freedom (ziyou), because "submission to instruction and

1 (Montesquieu 1989, p. 128). Interestingly, Montesquieu continues, "In the first dynasties, when the empire was not so extensive, perhaps the government deviated a little from that spirit." For Japanese and Chinese readings of this, see (Hou 2015), p. 320 [hereafter Hou Xudong].

2 (Hou 2015, p. 334), citing the Chinese: 查我中原民族，休養於專制政體之下已四千餘年，服教畏神，久成習慣.

3 Ibid. The Chinese reads, 非不知脱離專制，尊重自由.......知非君主政體不足以自立.

4 Such points have been registered by many authors, including Hou Xudong, and Arif Dirlik. For Dirlik, see (Dirlik 2011, 2008). 
fear of the gods" functioned as a vital check on despotism and was perceived to be the key barrier to the unchecked and unhampered self-assertion by subjects and rulers that demeans others. This wide circle of salutary fear is therefore the subject of our essay.

By our reading of a wide range of documents, both excavated and received, the more ideal the society and court, the greater and more pervasive the fear among the members of all groups with any access to power-fear justified as salutary caution or even dread on the part of the male or female whose communications with all others, living and dead, regardless of social status, were ideally to convey acknowledgment of the other party's potential or actual superiority at present or in future. The acknowledgement was predicated upon and signaled by a willingness to downgrade one's own person through a broad range of formal conventions, spoken and gestural. This early culture has remarkably little to do with modern notions of power, as this essay seeks to show. Instead it relied upon far more complicated notions of status, power, and authority embedded in the early empires in China, ${ }^{5}$ and, quite radically, posited a kind of equality of status for all members of the elite carefully designed to accord equal dignity to all. (We shall adduce examples of imperial fear, as well as the fear of the low-ranking).

In this paper, we shall use the single word "fear" as a shorthand phrase to express this tangle of feelings and actions, composed of salutary fear and exquisite courtesy, salutary fear of what might happen if ritual formulae were not scrupulously observed, preventing courteous exchanges from converting raw emotion into constructive behavior-in other words, salutary fear spurring exemplary motivation to undertake the exemplary act. Modern scholars of religion, following the anthropologists of the 1960s, have often focused on the mourning circle, and disputes over who was inside and outside of it, as practices evolved substantially down through imperial history in China. ${ }^{6}$ Here we propose to delve into a related topic, demonstrating how vast was the reach of the circle of fear during the early empires. Rather than being a concern of relatively few households (at most, the maternal, paternal, and sororal) comprising several tens of people in elite families, this circle of fear ideally encompassed not only anyone who in any way represented an actual equal, but also anyone who might in future become an equal in any one of dense interlocking hierarchies constructed in early China, those consisting mainly of inherited status; official rank; twenty-plus orders of honor or jue 爵 ${ }^{7}$ conferred for merit and for other reasons; seniority; gender; aggregate wealth; impressive demeanor (looks and speech), usually described as $d e$ 德 (charismatic or suasive presence), ${ }^{8}$ acquired high cultural learning or other technical skills; ${ }^{9}$ and guest-and-host relations, plus the range of relations modelled on those, including intrafamilial relations, patron-client relations, landlord and tenant, and teacher-student relations. (Note: the degree to which any of these hierarchies was foregrounded in a given social exchange depended substantially on how the precise situation at hand brought the other hierarchies into play.) Compared with the early Mediterranean world, where two main divisions (slave versus free) dominated discussions, in early China the desire to "not be enslaved" by people and things inevitably

5 The "early empires" (also known as the "classical era") are defined here as 323 BCE to 316 CE, with a sharper focus on Qin and Han, for two reasons: first, so many pre-unification authoritative writings were heavily revised by activist editors in late Western Han, so only the excavated documents (and not those "found") constitute evidence; and second, there is much more evidence for the Qin and the two Han dynasties than for Zhanguo, given the massive destruction of pre-Qin histories, intentional and coincidental. (By $323 \mathrm{BCE}$, all the great Zhanguo rulers had declared themselves as kings intent upon unifying China; 316 CE marks the conquest of all of North China by nomadic and semi-nomadic groups, and the consequent adoption by more people in both north and south of various types of religious Daoism and Buddhism.

6 Maram Epstein's work represents some of the best research on this subject. We recommend her (Li and Pines 2020, pp. 269-313).

7 There were twenty orders of honor, excluding the emperor, but also several gradations of servile status below those orders. These complexities have been studied before, aside from "servile status", which up until recently was dubbed "slavery", when it was far more often penal servitude for a set period (usually less than six years) or indentured servitude. For the twenty orders of honor, see (Loewe 2010, pp. 269-305).

8 For a counter example, see Dongguan Hanji 東觀漢記, 17.12, in the biography for Zhou Ze 周澤. In 69 Zhou Ze 周澤 was named Acting Excellency over the Masses (situ). It was found, however, that his conduct lacked sufficient gravitas and presence to hold the highest office in the land. (Fan 1965) [hereafter Hou Hanshu], 79B.2579 therefore says of him, “He to some degree forfeited any hope of becoming prime minister” 頗失宰相之望.

9 As argued in a forthcoming (early 2021) essay by Michael Nylan and Shoufu Yin, classical learning was often combined with other forms of technical knowledge in the early empires, such as ritual performance, the martial arts, or adjudication of legal matters. 
generated nuanced assessments, in which even the Son of Heaven at the apex of many of these interlocking hierarchies could be easily enslaved by others or himself, if he did not knowingly participate in exemplary fashion within this circle of fear, and so strengthen its effects. Distinctions between early Chinese and Mediterranean civilizations notwithstanding, the complexity of the social negotiations (and social dangers) might be fruitfully compared to those described by Jon E. Lendon, Carlin Barton, and others. ${ }^{10}$

Indeed, Barton has made the comparison between the "Tao of the Romans" and early Chinese theories of fear quite explicit. Put directly and drily, Barton writes: "Romans expected of one another a high degree of behavioral finesse, a sort of social Fingerspitzengefühl. Lapses were noted". The universal nature of fear in maintaining social relationships was registered by Cicero who wrote, "There is no one so wild as not to be greatly moved ... by the fear of reproach and dishonor". The "Roman way" was like the Confucian, Barton writes, in that things were approached (citing Analects 8.3) "in fear and trembling, with caution and care, as though on the brink of a chasm, as though treading on thin ice". ${ }^{11}$ This general anxiety and fear, Barton concedes, "demanded a degree of mutual surveillance and inhibition that modern Americans might find only in an Orwellian nightmare ... But to understand Roman culture, one must understand that the strictures of Roman tradition were also the necessary preconditions for the creation and existence of the Roman soul". ${ }^{12}$ Barton concedes a point for the Romans that we dispute here in relation to the early thinkers in China. Fear has, however, become so closely associated with despotism and monarchy that it requires an almost heroic act of imagination to feel our way into its salutary effects. ${ }^{13}$

Citing Rousseau and later Proust, Martha Nussbaum notes that "fear is the emotion of an absolute monarch" and that the "kings of France could not have compassion for the people they ruled, since they could not imagine any type of common world, or reciprocity, with them". ${ }^{14}$ Further, she writes that fear is "genetically first among the emotions". ${ }^{15}$ The feeling of weakness and dependence characteristic of the infant produced the "idea of empire and domination". ${ }^{16}$ In our view, a keen sense of the utility of salutary fear in early China complicates this discussion in wondrous ways. There, one is afraid to act alone because such an act would be an affront to humanity's inter-dependence, at once tempting fate, inviting retribution, and jeopardizing efforts to humanize tyrants.

Our paper consists of three main parts. The first outlines the negative treatments generally attached to autonomous action in the early empires, regardless of the actor. The second describes the language of command and of favor in situating fear and trepidation within highly ritualized scripts of visitation. The third explores the seeming paradox found in the classical era texts devoted to the politics of survival, in which the members of the governing elite are told to experience and express a strong sense of fear through ritual speech and gestures, as this is the single most important precondition for securing a sense of independent and dignified action. All parts of this picture are germane and contribute to the whole, and so all parts must be pieced together, if we moderns are to begin to understand the subtexts that undergirded many pieces of writing in the early empires in China.

But before providing a sampling of the representative sources, we adduce one simple yet unambiguous story illustrating how this circle of fear we describe worked in the early empires, citing the sudden reversal and unexpected downfall of Ban Gu 班固 (32-92). Ban $\mathrm{Gu}$, as most readers will recall, was one of two fathers of Chinese history and a member of the imperial consort clan whose immense wealth sufficed to build the largest repository

10 See, e.g., (Lendon 1997; Barton 2001).

1 Barton, Roman Honor, p. 20, 19, 26.

2 Ibid., 23.

Nussbaum's recent book underscores the connection, (Nussbaum 2018). She adds, "human life begins not in democracy but in monarchy."

4 Ibid., 30.

5 Ibid., 20, 22.

16 Ibid., 22, citing Rousseau, Emile: or On Education. 
of manuscripts in the entire realm outside the imperial palace itself. For most of his life, Ban lived a life of extraordinary privilege, so indulged by three emperors that he even enjoyed special access to the inner apartments of the palace and palace library, day or night. Then an allied imperial consort clan family, the Dous, were dismissed from power, and Ban was implicated in the Dou family misdoings, and predictably dismissed from office. ${ }^{17}$ He was duly imprisoned, but no one in the capital expected him to remain in jail for long, given his family's impeccable connections, their ability to intervene in the administration of justice, and Ban's own personal merits, as his biographer explicitly states. ${ }^{18}$ However, no one among Ban's peers had reckoned on a complicating factor: sometime earlier, a certain Zhong Jing 种䫧, was out walking, when a servant or slave ( $n u$ 奴) of Ban barred the way to Zhong so that Ban's carriage could proceed. Zhong Jing's clerk then hit Ban's servant with a stick, at which point Ban's servant, who was drunk, cursed the clerk. Zhong Jing, feeling insulted and enraged, bided his time, thinking that Ban's favor at court was such that there was nothing he could do about it for the moment. But that did not prevent Zhong Jing from nursing the grievance (xin xian zhi 心銜之), while Ban clearly thought the altercation of no great import, when the wiser course would have been to apologize abjectly, profusely, and repeatedly. As it happened, by the time when Ban was imprisoned, Zhong Jing had become the Prefect of Luoyang (the man in charge of the capital prison), and he felt no compunction about avenging the earlier slight to his dignity. Indeed, he saw to it that Ban Gu at age 61, then in his prime and at the height of his powers in all senses of the word, quickly expired ignominiously in his prison cell, and although an imperial edict later blamed Zhong for the mistreatment, the post-facto indictment did the Ban family little good. What compels our interest here is this: Ban's biographer, Fan Ye, plainly assigns the real blame for Ban Gu's unexpected death to Ban's own ill-advised failure to be courteous enough in the first place. Fan writes,

He was unable to use his wisdom [in classical learning] to avoid the punishment by death. That being so, Ban, for his own part [like Sima Qian before him], had his physical person subjected to execution and his corpse exposed in the marketplace. Alas! For this reason, the men of antiquity turned their analysis to the most minute problems of self-scrutiny! 不能以智免極刑。然亦身陷大戮。古 人所以致論於目睫也. ${ }^{19}$

\section{Freedom and Monopoly/Despotism Defined}

In early imperial texts, for instance, zhuan 專 and ziyou 自由一the two terms that would become "despotism" and "freedom" in early modern and modern writings-were aligned, not opposed. ${ }^{20}$ Those who acted on their own authority without fear were "acting on their own authority and following their own inclinations" (zhuanji ziyou專己自由) or "punishing and rewarding in accordance with their own desires" (wei fu ziyou 威福自由). ${ }^{21}$ Those worthy of the designation of "true kings", by contrast, feared acting alone and on their own authority. The Hanshi waizhuan, a Han Odes tradition functioning as an authoritative commentary on the classic, quotes Kongzi's teachings on the Odes to that effect:

17 Hou Hanshu 40B.1386.

18 Rafe de Crespigny, in his (de Crespigny 2007), writes, somewhat misleadingly, "the Prefect of Luoyang Chong Jing, an old enemy, had him arrested. Ban Gu died in prison." He then alleges that it was the Dous' downfall that brought about Ban Gu's death. In failing to appreciate the significance of the backstory that explains why the Prefect's malicious behavior, he fails in this instance to alert readers to the complexity of the situation.

19 This is a free translation, which means something like "the pot calling the kettle black." Ban Gu should not have been so arrogant as to ridicule for Sima Qian for being condemned to castration, as Ban Gu himself was so condemned. The Li Xian 李賢 commentary to the Hou Hanshu quoted at HHS 40B.1386 connects this passage to Shiji 41.1748, where a Qi emissary criticized the ruler of Yue for being able to see the smallest faults of his enemies ("smallest hair") but failing to see his own faults (analogized to his own eyelashes). Our translation attempts to capture this.

20 As one anonymous reviewer correctly noted, ziyou 自由 is not frequently attested in early sources. Nonetheless, it exists, and moreover the alignment of ziyou with words like zhuanji 專己, for instance, in the early sources helps create a path hitherto not taken in thinking through the constellation of political values in early China.

21 Hou Hanshu 45.1547 and 10B.437. 
Kongzi said: "The wise king has three fears. First, as he resides in a high position, he fears that he will never hear about his faults. Second, whenever he gets his own way, he fears that he will become arrogant. Third, at hearing the highest and best principles for governing the world, he fears that he will never be able to put them into practice". 明王有三懼 : 一日處尊位而恐不聞其過, 二曰得志而恐驕, 三日聞天下之至道而恐不能行. ${ }^{22}$

Each fear concerns the dangers of acting alone from a position high above others. The early thinkers would have embraced the old English proverb, which puts it, "He who climbs higher than he should falls lowers than he would". ${ }^{23}$ For anyone who occupies the highest post in the realm, any misstep can lead to disaster for the throne and the ruling house. One of Kongzi's examples shows two types of fear: fear and reverence in the face of a teacher and fear in the face of the ancestors:

Long ago, Duke Huan of Qi, having got Guan Zhong and Xi Peng, was able to face south [as hegemon/overlord of all]. Duke Huan remarked, 'My getting the two of you in my service got me two sets of eyes that were all the more acute, two sets of ears that were all the keener. I dare not rule on my own authority, usurping the proper authorities. I have submitted this [recommendation] to the prior kings in heaven.' This, they say, is the ultimate way, and yet the fear is that the powerful will not be capable of acting in this way. 昔者、齊桓公得管仲級 朋。南面而立。桓公日。吾得二子也, 吾目加明, 吾耳加聰, 不敢獨擅, 進之先 祖。此聞至道而恐不能行者也. 24

The ode in question ("Xiao wan" 小宛), ${ }^{25}$ cast by the Mao commentary as the heartfelt expression of the immense dread felt by all people of dignity under an oppressive ruler, is here deployed for a starkly different purpose: to describe the salutary fear of "a great king who assumes a position high above others" 大王居人上. The very ambiguity and flexibility of the poetic lines, which never once identify the fearful protagonist, made it easy to transfer the application from what was originally cast as unnecessary and counter-productive fear felt by subjects toward a wicked ruler to the salutary fear of a good ruler.

While we are still on the subject of hegemonic, royal, and imperial fear, let us review a few examples from the Classics and standard histories of early China. We might begin with excerpts from the Documents classic insisting such fear is ordained by Heaven and the ancestors. The "Punishments" chapter, for example, describes right-thinking in terms of fear:

The majestic authority and mana of those in power truly is to be feared, and charisma shining bright is truly to be deemed bright ... For the various parties in common must take seriously the fearsome majesty of Heaven and his ruler [and so act with utmost care, and indeed refrain from acting, when administering the laws] ... You must always fear punishment. It is not that Heaven is unjust. It is rather that it falls on [fallible] humans to decide how to apply its decrees. 德威 惟畏德明惟明... 共嚴天威...永畏惟罰。非天不中。惟人在命。26

The "Weizi" 微子 chapter in the Documents supplies the necessary corrective, when "There have been refusals to regard the awesome with awe, and the king has failed to

22 Hanshi waizhuan 7.13.

23 English proverb, quoted in (Mantel 2020, p. 241).

24 Hanshi waizhuan 7.13, with "the powerful" implied. For a slightly different translation, see (Hightower 1952, p. 237). A helpful discussion of these issues appears in (Sanderovitch 2017, pp. 39-41).

25 Odes classic, Mao no. 196 reads: 温温恭人/如集于木/惴惴小心/如臨于谷/戰戰咕咕/如履薄冰。

26 Documents classic, "Punishments" (sections 25.4, 6, 7); cf. Legge, pp. 610-11. All translations from the Han-era Documents have been reconstructed by Michael Nylan and He Ruyue, for a forthcoming translation (2021), prepared for the University of Washington Press. We supply references to the Legge translations from The Shoo king (London: Trübner, 1861-72) simply for the reader's convenience, since Legge bases his translation on Cai Chen's 蔡沈 (1167-1230) understanding of the early fourth-century pseudo-Kong Documents, a double departure from the Han-era preoccupations; very distant from Han-era thinking would also be the Shisan jing zhushu 十三經注疏 edition of Ruan Yuan 阮元 (preface 1815), available at http:/ / hanchi.ihp.sinica.edu.tw) or (Gu and Liu 2005, vol. 4). NB: different early editions use 於/于 interchangeably. 
resort to the senior advisors", with the downfall ascribed to "undutiful behavior", ${ }^{27}$ when "Above, he does not fear disasters. Below, he does not fear the worthy men. He goes against the head of the elders. He does not use their advice". ${ }^{28}$ Right-thinking and once-supremely loyal and effective servants of the throne must abandon it, to pave the way for a new and better dynasty. "We shall not turn back from our decision to flee or regret it", ${ }^{29}$ Weizi remarks upon closing, essentially sealing the fate of his unwise ruler he knew insufficient salutary fear.

More often, the Documents enjoins its readers (all members of the governing elite, including princes of the realm) that the throne-holder who manages to keep that throne is no more than the servant of all who have ever lived and died, past and present, including his nominal subordinates and those residing in Heaven, the Lord on high, the prior kings, and the ancestors in Heaven. As the "Shao gao" frames it,

May he [the current occupant on the throne] find a way to be able to establish friendly relations of trust with the little people on a large scale. Today is favorable, yes, but the king dare not delay, lest he look back and fear frequent gossiping by his people. May the king proceed and extend the work of the Lord on High. May he serve and be of service to the lands at center ... May the king duly attend to what he fashions. He may never not attend to building up his charisma [for the sake of the health of the body politic he serves]. 丕能諴於/于小民。今休。王不 敢後、用顧畏于民碞。王來紹上帝。自服于土中 ... 王敬作所。不可不敬德. 30

Turning to officials and the salutary fear they know when they have become sufficiently mindful of their duties, we find so many examples drawn from the Classics, masterworks, and histories that we hardly know where to begin. The Odes "Zhengyue" 正 月 portrays the fear that members of the governing elite feel toward their superiors. But the poem implies that there is salutary fear and craven fear. Let us examine the Odes lines to see what we can learn,

- They say heaven is high, but 謂天蓋高

- I dare not not crouch. 不敢不跼

- They say earth is firm ground, but 謂地蓋厚

- I dare not not tread lightly. 不敢不踏

- Piteous are we of recent times, 哀今之人

- How have we come to be as skittish as eft! 胡為虺蜴 31

Xun Yue 荀悦 (148-209 CE) used that poem to highlight the problem of speech in the former Han:

One never dares take a stand in the world, how much worse, for he who dares to take a stand at court! Guarding oneself never means escape from harm! How much worse, for he who dares to protect himself from his peers! The faultless find themselves slandered nonetheless, and how much worse, for he who dares to offend! Shutting one's mouth never brings relief from calumny. Far worse is it for he who dares to talk straight!

本不敢立於人間。況敢立於朝乎。自守猶不免患。況敢守於時乎。無過猶見誣 枉。而況敢有罪乎。閉口而獲誹謗。況敢直言乎。32

27 Documents classic, “Weizi” (section 9.2; Legge, p. 276), with the Chinese reading: 乃冊畏畏。不用老長; Ma Rong' commentary for the line says, “I fear the downfall due to undutiful behavior, so what should I do?" 恐顛墜於非義, 當如之何也.

Documents classic, “Weizi" (section 9.2b; Legge, p. 278): 我不顧行遯.

30 Documents classic, "Shao gao" (sections 17.2, 3; Legge, pp. 428-29).

31 Odes classic, Mao ode 192 ("Zhengyue" 正月), from the "Xiao ya" section usually thought to reflect the concerns of the relatively high-ranking. The translation is the authors' own, in light of Zheng Xuan's reading of 胡為虺蜴:"Their nature is such that they flee at the first sight of others" 虺蜴之 性, 見人則走 (Ruan Yuan, 399-1). We note that a modern therapy for skittishness is called EFT (Emotional Freedom Therapy).

32 Xun Yue 荀悦, Qian Hanji 前漢紀, juan 25, 439. (Refs. to Zhang 2005). 
In reading this Odes selection, it is perfectly obvious that a bad ruler sits on the throne, since "Guarding oneself never means escape from harm! ... Shutting one's mouth never brings relief from calumny". Plainly the ruler is too apt to heed slanders, from those craven individuals, who though less-than-honest, surround him. Equally plainly, this a situation that, by definition, would never prevail at the court of a wise ruler, one who himself treads lightly, lest his misjudgement of a person bring harm the body politic. For salutary fear in ritual acts works as well for states as for individual people and families. For an example of one whose exquisite caution saved his small state from peril, despite its position sandwiched between far more powerful neighbors on the warpath, one need look no further than Zichan 子産, prime minister of Zheng 鄭 (d. 522 BC), during the Chunqiu period. Of Zichan, Kongzi (also known as Confucius) had this to say: "This sort of conduct sufficed to put his kingdom on firm foundation", as he knew how, through artful ritual, to harmonize the local lords. ${ }^{33}$

We turn now to one of many examples we might adduce from an early standard history, an entry that concerns an intriguing application of the "Great Plan" chapter of the Documents classic:

At the time there was a charge issued to the General Attacking the South Xiahou Shang that stated: "You, my most beloved and trusted general, We appoint to this special task. Your favors will suffice to make men die for you and your grace will command their hearts. You have the power to induce mighty fear or confer good fortune, to kill or to let people live". Shang showed this to Jiang Ji.

詔征南將軍夏侯尚日。「卿腹心重將, 特當任使。恩施足死, 惠愛可懷。作威作 福, 殺人活人。」尚以示濟。

When Jiang Ji arrived at court, the emperor asked: "What have you found out about the ethical teachings that prevail in the realm?" Ji responded: "There is nothing good to report, but I have now seen talk that would suffice to bring a kingdom down". Emperor Wen was visibly furious and asked what he was talking about. Ji gave a detailed response, "As we all know, the phrase referring to the power 'to induce fear or confer fortune' is a clear warning [to rulers] found in the Documents [in Part 8 of the Plan]. That 'a true Son of Heaven never says words in jest' was a precept taken seriously by the Ancients. ${ }^{34}$ Your majesty must look into this matter carefully". With this the Emperor understood the problem and sent someone to get hold of his earlier edicts. ${ }^{35}$

濟既至, 帝問日。「卿所聞見天下風教何如? 」濟對曰。「未有他善, 但見亡國
之語耳。」帝忿然作色而問其故, 濟具以答, 因日。「夫作威作福』, 書之明
誡。『天子無戲言』, 古人所慎。惟陛下察之!」於是帝意解, 遣追取前詔。

Throughout the two Han dynasties, the phrase zuowei zuofu 作威作福 [literally, "to induce fear or confer good fortune"] was used to critique overly powerful ministers who had overstepped the dividing line separating the powers of the ruler and those of ministers, by doling out rewards and punishments on their own authority. Here, a single invocation of this four-character phrase from the "Great Plan" seems to awaken Emperor Wen to his duty not to delegate powers over life and death to his underlings.

33 Zuozhuan, Lord Zhao, Year 13: 於是行也, 足以為國基矣. The best essay we have seen on “harmony" is by (Gentz 2020, pp. 37-84).

34 Liu Xiang's Shuoyuan illustrates this point through an anecdote that features Zhougong (also known as the Duke of Zhou) and the young King Cheng.

35 (Chen 1959, p. 14.451). 


\section{Visits and Gifts/Fears and Favors}

The Yili 儀禮, the oldest of what were to become eventually the three Rites classics, ${ }^{36}$ evinces neither gratitude nor favor. Given the amount of time spent discussing gift-giving in connection with other social niceties, this absence, in itself, prompts deep surprise. After all, following Mayfair Mei-hui Yang's brilliant 1994 account of the pervasive operations of Chinese guanxi 關係 in today's PRC, students of China expect ritual texts to be preoccupied with gifts and favors that are to be efficiently reciprocated by more gifts and favors. ${ }^{37}$ Our research into the rituals of the early empires reveals that two markedly different grammars were used in connection with many rituals. One grammar talks of favors whereas the second talks of command, and the relations between those two types of grammar and fear differ greatly. Either an agent appears as one of the "givers and receivers of commands" (ming 命) or as one of the "givers and receivers of [lucky, i.e., undeserved] favors" (xing 幸). The chasm between "commands" and "favors" was foundational in early Chinese thought, as we will see. ${ }^{38}$ When interacting with fellow "givers of commands", the agent must grant the counterpart the dignity afforded those worthy of commanding others. At the same time, when interacting with fellow "givers of favors", the agent must attend to the favor that has been or will be bestowed. In this section, we reflect on the way these two grammars elicit different, and sometimes contradictory, feelings of fear.

The Yili, as we will see, is predicated on the language of command, entailing its own cycle of fear, that imparts a ritual chill distinctly at odds with the warmer world of favors on display in the early standard histories at the major courts of the day. In the Yili scripts, the agent (generally male) fears acting without authorization, lest the agent inadvertently humiliate his counterpart and thus jeopardize the good feelings and trust of other members of the governing elite at any rank. ${ }^{39}$ And while the recipient in the world of favors had better not forget the favors rendered, the gentleperson in the world constructed in the Yili who deigns to plunge into social exchanges must cast himself as full of dread.

Close readings of the formulaic language in two early texts-the first, a letter excavated at Liye 里耶 and the second, an Yili chapter entitled "Rituals for Visits Among Gentlemen" 士相見之禮—lay bare the major differences between the two domains, each with its own distinctive script. For these two early texts, superficially so similar, convey contrary messages to those sufficiently "in the know", astute readers of classical Chinese then and now, even if casual, uninformed, or disinterested onlookers in any period might miss the micro-aggressions and micro-concessions. After reviewing these two documents, this section will turn to consider a discussion of gift-giving in the Mencius (also known as Mengzi), in order to establish the precise point where the fear lies in these all-important rituals of exchange, a point often overlooked.

The letter found in the Liye 里耶 cache is usually described as a "personal letter" between a certain Yuyan and Zibo, but the literary exchange is entirely formulaic and it registers no personal details or requests such as are found in other letters from the period. The Liye letter, accordingly, is best understood as a prime example of a ritual template in which the names and gift amounts could be changed. Yuyan writes to Zibo in order to return a "favor" 幸:

Police Chief Yuyan dares to so bold in asking after Zibo: Are you without ailments? Have you found your work to be too troublesome? I have no reason to inquire after you and [can only] offer this letter as a show of respect. I dare to pay you a visit. Earlier, you favorably granted that which I requested, so now I

36 Certainly, the Yili dates to the pre-unification era, judging by grammar and contents. The Liji and Zhouli, by contrast, appear first in late Western Han. The Three Rites classics are a grouping invented by Zheng Xuan. For further information, see (Yang 2007).

37 Yang's first book was (Yang 1994), based on her thesis of 1986; multiple essays devoted to the same topic have followed.

38 This topic is explored at greater length in (Wilson 2021), esp. chp. 2.

39 As the Yili describes the activities of the shi 士, the lower-ranking members of the aristocracy who may be called up for court or battle service, usually the subject is male; ergo the pronoun use here and below. In its descriptions of mourning and marriage rites, women enter the picture, but ordinary visitations are left generally to the men, as they are in the Annals classic and its traditions. 
dare not be without a return gift. ${ }^{40}$ Today, I bow before you and offer you one shi of food.

\section{校長予言敢大心多問子柏：柏得冊恙? 柏得冊為事統乎? 冊以問, 進書為敬。敢 謁之。／前所謁者（諸）柏, 柏幸之，不敢亡（無）賜。今為柏下之，為柏寄食 一石。41}

The social logic beneath the formulae is clear. Zibo had shown favor to Yuyan, either by granting an audience or responding to some request. It is marked as a "favor" to denote that Zibo's response exceeded what might have been done under such circumstances, thus creating a debt. The debt incurred by Zibo's magnanimity might be marked, at least at the level of social courtesy, as a possible affront to Zibo as well. (Other letters from the period mark the giver's actions as both "humiliation" and "favor", with the problem of humiliation discussed below.) In response to Zibo's favor, Yuyan says, "I dare not be without a gift". Yuyan remembers the favor and is compelled to return it. The social logic, by the way, mirrors that found in the Annals classic and the Zuozhuan traditions: the guest has always placed himself in an inferior position vis-a-vis the host, even if the inferiority is feigned or temporary. This mode of characterizing the social interaction in terms of favor/gratitude is notably absent from the Yili text we cite at some length below, in our translation.

For the ritual protocols for the visit between peers, as scripted in the "Rituals for Visits Among Gentlemen" 士相見之禮 in the Yili 儀禮 [hereafter “Ritual Visits” for simplicity]， outlines a ritual primarily concerned with authorization and humiliation. The guest who arrives at the door has been "ordered" to come, and he dare not present himself without proper authorization. The ensuing exchange is a virtual battle over who commands whom. Finally, the host is forced to surrender, with the declaration that he cannot but obey the guest's commands. (Note well: insofar as the initial hierarchy conventionally attached to host vs. guest is here reversed, the lengthy process that unfolds in the exchange equalizes the two parties in the exchange.) As the back-and-forth is wonderfully complex, we translate it in full here:

Etiquette for audiences between gentlemen: As for the gift, in winter, use a pheasant; in summer use dried [pheasant]. [The guest] presents it with the head to the left. [The guest] says: "I have wished to present myself [before you], I but had no reason to come. ${ }^{42}$ So-and-so ordered me to present myself [before you]". 士相見之禮。摰, 冬用雉, 夏用腒。左頭奉之, 日。某也願見, 無由達。某子以 命命某見。

The host replies: "So-and-so ordered me to see you. Milord has humiliated himself [by coming]. I beg that milord return home and I will make haste to come before you". 主人對曰。某子命某見, 吾子有辱。請吾子之就家也，某將走見。

40 As this sentence is difficult to interpret, alternative translations exist. We generally follow the reading proposed by (Wu 2017, pp. 482-83), knowing that the line might also be translated as a combination letter including both Yuyan and Zibo's writings. If the latter, then this line might then be read as the beginning of Zibo's response: "Early when you visited me, I was shown a great favor [meaning, I was honored by your visit] and thus dare not be without a return gift." In this reading, the last line would be someone offering the letter and gift "for me" 為柏 (We thank our colleague Zheng Yifan for this insight, (Zheng 2020).

41 Liye 8-823+8-1997. See (Chen 2012, p. 233.) Enno Giele translates a similar letter in Giele, (Richter 2015a, p. 366). Giele renders the same opening formula as "happily sends his very best greetings." See the similar letter at Liye 7-4 http://www.bsm.org.cn/show_article.php?id=2068. For epistolary conventions, we urge readers to reconsider the oft-cited arguments by Robin D.S. Yates, "Chapter Soldiers, Scribes, and Women: Literacy the Lower Orders in Early China", 339-69, in (Branner and Li 2018) Yates takes a few letters by soldiers and women as solid "proof" of high rates of literacy in the population at large, forgetting that professional scriveners wrote for the unlettered. Of greater interest is the book by (Richter 2013); and her edited work, (Richter 2015b).

42 We consulted multiple translations and commentaries to produce this translation, but mainly we rely upon the Yili text, with its commentary by Zheng Xuan 鄭玄 (127-200) and Tang sub-commentary by Jia Gongyan 賈公彦, as gathered in (Wang 2008). We have also consulted three translations: (1) (Couvreur 1928); (2) (de Harlez 1890); (3) (Steele 1917). Zheng Xuan remarks: 言久無因緣以自達也。某子，今所因緣之姓名. Couveur, p. 58: “je n'ai jamais eu de relations avec lui." Harlez, p. 47: "ne sait point comment s'y prendre (n'ose point le faire)." Steele, p. 42: “but have had no justification for asking for it." 
The guest replies: "I am unworthy, so do not disgrace yourself by ordering me. I beg that you will finally grant me this audience". ${ }^{43}$ The host replies: "I dare not put on a display of authority. ${ }^{44}$ I persist in asking my lord to return home and I will make haste to come before him". 實 對曰。某不足以辱命, 請終賜見。主人 對曰。某不敢為儀, 固請吾子之就家也, 某將走見。

The guest replies: "I dare not put on a display of authority, so I persist in begging". The host replies: "I have persisted in declining, but this has not been allowed (lit. "ordered"). I will come out to see [you]. I hear that milord has brought a gift. I dare to decline the gift". 實對日。某不敢為儀, 固以請。主人對日。某也固辭, 不得命, 將走見。聞吾子稱摰, 敢辭摰。

The guest replies: "Without the gift, I dare not show myself". The host replies: "Do not engage in these rituals-I am not worthy. I dare to persist in declining [the gift]". The guest replies: "Without the support of this gift, I dare not show myself. I persist in begging”. 實對日。某不以摰, 不敢見。主人對日。某不足以 習禮, 敢固辭。實對日。某也不依於摰, 不敢見, 固以請。

The host replies: "I also persist in declining, I but have not been allowed to do so. Dare I not respectfully obey!" The host goes out the gate to meet [the guest]. He bows twice. The guest responds by bowing twice. The host salutes and enters the right side of the gate. Carrying the gift, the guest enters the left side of the gate. The host bows twice and then accepts [the gift]. The guest bows twice and offers the gift. [The guest then attempts to] exit. The host begs for an audience. The guest returns for the audience. [When the guest] departs, the host sees him out the gate. [The host] bows twice. 主人對日。某也固辭, 不得命, 敢不敬從! 出迎於門外, 再拜。貝荅再拜。主人揖, 入門右。實奉摰, 入門左。主人再拜 受, 實再拜送摰, 出。主人請見, 實反見。退, 主人送於門外, 再拜。

The [former] host now pays a return visit, taking the gift [with him]. He says: "Earlier, when milord humiliated himself [by visiting me] he demanded that I come before him. I beg to return this gift to the usher". ${ }^{45}$ The host responds: "I already had an audience. I dare to decline". The guest responds: "It is not that I dare to request an audience, I [simply] beg to return the gift to the usher". 主人 復見之, 以其摰, 日。薌者吾子辱, 使某見。請還摰於將命者。主人對日。某也 既得見矣, 敢辭。實對日。某也非敢求見, 請還摰於將命者。

The host says: "I have already had an audience. I dare to persist in declining". The guest responds: "I dare not request to be heard. ${ }^{46}$ I persist in begging through the usher". The host responds: "I persist in declining, but I have not been permitted to decline. Dare I not obey?!" The guest presents the gift and enters. The host bows twice and accepts [the gift]. The host bows twice and gives the gift. He then exits. The host sees him out the gate. He bows twice. 主人對 日。某也既得見矣, 敢固辭。實對日。某不敢以聞, 固以請於將命者。主人對 日。某也固辭, 不得命, 敢不從? 實奉摰入, 主人再拜受。實再拜送摰, 出。主 人送於門外, 再拜。

43 The phrase ruming 辱命 appears in Yili “Shi hun li” 士昏禮 (p. 159). The context is nearly identical. Steele, p. 42: “I cannot bring disgrace on you by obeying this command." Harlez, p. 47: "Je ne pourrais déshonorer l'ordre (que vous me donneriez de venir chez vous)." Couveur, p. 58: "je ne suis pas digne que le maître de la maison veuille s'abaisser à me fair visite." The phrase ruming also appears in Liji 禮記 “Tan gong xia” 檀宮下 : 君無所 辱命. Also see Zuozhuan, Duke Xi, Year 24: 何辱命焉. Translation, 24.1b, p. 375: “Why condescend to issue an order for me to depart?” Duke Xiang, Year 3, 何辱命焉. Translation, 3.7, p. 905: “Why deign to issue a command?" Chinese text and translation from, (Durrrant et al. 2016).

44 Steele, p. 42: "I do not dare to set an example as to how a reception of this kind should be conducted." Couveur, p. 59: "Je ne me permettrais pas de fair de pures et vaines cérémonies (c'est sincèrement que je parle)." Harlez, p. 47: "Je n'oserais faire des cérémonies, (ce que je dis est sincere)."

45 Steele, p. 44, uses "usher."

46 The Tang subcommentary suggests that the wen 聞 is a further elaboration of the jian 見 from the first line 上云非敢求見, 已是不敢當, 此云“不敢以 聞'，耳聞疏於目見，故云又益不敢當也 (p. 172). 
The entire exchange is set in motion by a command (ming 命) issuing from a third party. The exchange is completed only when the guest has persisted to such an extent that the host is essentially forced to obey the guest's commands by taking the gift and welcoming the visitor. Allowing the other to complete this visit-even allowing him to command one-is to allow the other to humiliate himself. Allowing the guest to command the host at least apportions the humiliation equally. For this reason, the return visit is absolutely essential. Each person gets to play the humiliated party once.

As the foregoing has shown, the Liye and the Yili texts each describe a performance of "respect" (jing 敬) and gift giving, yet closer examination reveals the remarkable difference in the practical logic underpinning the exchanges. Whereas in the first, Yuyan fears that he will be ungrateful or forgetful, in the second exchange, the guest and the host both fear that the other may have suffered some sense of humiliation ( $r u$ 辱). The host is compelled, then, to visit the guest later to alleviate the humiliation suffered by the guest on the initial visit. So whereas Yuyan thinks of repayment; the Yili host thinks, when returning the favor, of reparations. These two thoughts are tied to quite different emotions, we contend.

Few early texts improve upon the Mencius when articulating this delicate difference between the two contrasting ideas of respectful exchange and respect-as-obligation. In one reported conversation with a disciple in that text, Mencius shows that he fully appreciates how socially binding the ritual protocols of gift-giving are. Nonetheless, Mencius, following the model of Confucius, refuses to be taken in by the conventional social logic of favors. Here is the story that illustrates this push-pull: Mencius heaps praise on Confucius for the precise way the Sage chose to pay a return visit for Yang Hu's 陽虎 visit: he intentionally went to Yang's place when he knew that Yang Hu was bound to be away from home. Plainly to gentlemen of the time, including Confucius and Mencius, when Yang Hu brought a gift for Confucius at his home and then left it, Yang thought by taking such trouble he would incur a profound obligation on Confucius's part, since he, a man of significantly higher rank at court, had favored the home of Confucius not only with a visit (Yang Hu's temporary presence) but also with a gift (Yang Hu's permanent token of esteem). ${ }^{47}$ Confucius intuited Yang $\mathrm{Hu}^{\prime}$ s intention, and he wanted nothing to do with Yang $\mathrm{Hu}$, a man who had already humiliated him several times before, when he was a youth. ${ }^{48}$ More mature now, Confucius knew how to utilize ritual to position himself in such a way that he could not now, or in the future, ever be subordinated to Yang Hu's wishes. As Mencius realizes, it took a wise man to devise a method to simultaneously fulfil his obligations, thus preserving the dignity of the other, and to avoid the traps laid by another, lesser but more calculating man.

Then in a second passage of conversation with a disciple, ${ }^{49}$ Mencius' interlocutor asks what "attitude of mind" one should bear while gift-giving. Mencius responds, "Respect" (gong 恭). According to Mencius' analysis, a gentleman generally therefore feels obligated to accept a gift from a superior without question, precisely because it would be disrespectful to inquire of another, mentally or verbally, "Did he get the thing by righteous or unrighteous means?" As long as the gift is proffered with ritual respect, it can be accepted. This important caveat- "with ritual respect" — had already been discussed in a previous exchange, ${ }^{50}$ when Mencius' student pressed him as to why he had refused to accept a gift from the ruler of Qi, his superior. By Mencius' own account, he did not accept a gift in Qi because, "there was no occasion for a gift, and to send someone a gift in the absence of any occasion for it is bribery. Is it possible to procure ( $q u$ 取) [the possession of] a gentleman with such a bribe?" 若於齊, 則未有處也。無處而餽之, 是貨之也。焉有君子而可以貨取 乎? ${ }^{51}$ Exactly how a gentleman's person might be "procured" or "seized" (qu) for service is

47 Mencius 3B/7; (Lau 1970, p. 112). All refs. to D.C. Lau are to that edition or to subsequent reprints. We cite this as the best translation available, for non-readers of Chinese. 
left out of the Mencius, but the Eastern Han commentator Zhao Qi 趙岐 could not resist describing the feeling that a bribe is meant to instill in a person:

Absent a proper pretext ( $y i$ 義) or occasion for the gift, this [gift] would be an attempt to procure ( $q u$ 取) the subject by using something of value. The giver wants to compel (shi 使) the subject to cherish the favor bestowed (huai hui 懷 惠). But how can a true gentleman be procured with something of value? By definition, the true gentleman permits only what is permitted by ritual propriety ( $l i$ 禮). 義無所處而餽之、是以貨財取我、欲使我懷惠也。安有君子而可以貨財見 取之乎? 是其禮當其可也. 52

Only the ritual order protects a person of true sensitivity from experiencing the violation felt by a person who is capable ( $k$ 可) of being "procured" and "seized" ( $q u$ 取), since he can be lured by money or other valuable commodities. Of course, infinite permutations of this were possible in real life, judging from the standard histories and masterworks. One strategy might involve, for instance, allowing oneself to be "seized" as a way of openly humiliating oneself in order to highlight the crudeness of the other party. But undeniably, those keen on social manipulation wanted the recipient of the gift to feel beholden. In these three passages from the Mencius, the compiler tries to sketch exactly what rules an ideal social order would follow, if blessedly freed from the logic of "favor" entirely. Indeed, as if to underscore how important this issue was to Mencius, he says elsewhere that it was precisely Confucius' unwillingness to curry favor with wellconnected people or to seek easy access to power that showed how much the gentleman Confucius was. ${ }^{53}$ (Xunzi took up the same theme, when he spoke of the gentleman's desire to "not be enslaved" by people or by things, as we will see).

We might do well to bring Mencius' thinking into dialogue with the Liye and Yili scripts in the following way. The Yili establishes a script in which all participants are viewed as dignified persons with an equal ability to issue commands and feel humiliation. As each person is capable of issuing commands, each person must habitually be approached with a degree of respect, reverence, and fear. Mencius preserves this aspect of gift-giving ritual explicitly in his assessment of the right attitude of mind-"reverence" - and implicitly in the story of Confucius' obliged return gift to Yang Hu. At the same time, however, Mencius refuses the logic of favor. He will not be "seized" by an irreverent gift aimed at purchasing his loyalty. Mencius, by this portrayal, is reverent and appropriately fearful in the face of certain ritual norms, but fearless, to the point of appearing self-contradictory to his own students, in the face of inappropriate gifts. The Yili script, rather than the "favor" of the Liye script, thus better expresses the kind of ritual relation Mencius strives to project. Ritual fear and reverence is what preserves the dignity of self and others. "Favor", while never unequivocally rejected in all circumstances, opens up a path to abuses of all sorts, including unlawful seizure and enslavement.

In fact, there were well-developed ways-so conventional as to seem clichés-to shift a conversation from the "favor" script to the "command" script in early Chinese rhetoric. These rhetorical motifs then powerfully blended fear and fearlessness. "Favor", the motif goes, invigorates the person, giving the recipient an extraordinary boost-so much so that he or she may well forget about everything else, even the value placed on life, in the rush to fulfill the duty incurred and return the favor. Doubtless, this kind of show of fearlessness was buttressed by the dreaded prospect of humiliating a patron, even inadvertently. In some cases, however, the patron is not an actual person in the flesh who may be hoping to purchase added loyalty or in some other way arrogate the physical person to his own use. Rather, the patron is the imagined idealized person who acts with integrity and dignity, and thus commands respect and reverence in return. There are many examples of this favor-sublimated-to-command script, a few of which we adduce here. In the Chuci 楚辭, for instance, the author of the "Jiu Bian" 九辯 says:

52 Mencius commentary, cited in Mengzi zhushu 75-1.

53 Mencius 5A/8; D.C. Lau, p. 147. 
I would willingly gag my mouth and say nothing, Had I not once enjoyed rich favors from my lord. 願銜枚而無言兮，嘗被君之渥洽。

And in the same poem:

My lord has banished me far off and will not examine my cause:

Even though I wish to be loyal, I have no means to show it.

I should like to keep silent and sunder all links with him.

But I dare not forget the great favor (hou de) he once showed me.

君棄遠而不察兮，雖願忠其焉得?

欲寂漠而絶端兮，䎇不敢忘初之厚德. 54

The critique the speaker utters against his ruler is complicated by the favor the ruler once showed him, favor that has invigorated the speaker with a strong sense of propriety. Only a return gift of integrity is a worthy return for such earlier favor; mere sullen obedience would not suffice. Something similar to this logic surfaces throughout the Han histories as well. In one notable case, an imperial emissary angers the emperor with his claim that imperial favor demands that he prosecute an imperial favorite:

Your servant is most fortunate (xing 幸) to be made an emissary. The office demands that I attack and promote impartially. I dare not cower before the powerful positions of those most honored and favored by you, and thereby block your penetrating insight. 臣幸得銜命奉使。職在刺舉。不敢避貴幸之勢、以塞視 聽之明. .5

Official administrative documents evoke similar language as well. In a recently excavated legal case from Wuyi guangchang 五一廣場 dated to $104 \mathrm{CE}$, local officials are accused of running a moonshining scheme with the help of convict laborers and others under their command. In the course of enumerating the specific crimes of the miscreants, the document also laments that the officials did not return the favors they had received:

In holding office [the offenders] were blanketed with favor (en 恩), and despite that, they did not strive with all their might to act loyally [in return]. Nor did they cleanse their hearts [of venal susceptibilities] and preserve themselves [from wrongdoing]. 蒙恩在職、不思竭力盡忠。酒心自守. ${ }^{56}$

This formula celebrates the felicitous effects that "favor" should by rights exert on the recipient, securing his dignity, and thus encouraging the recipient to "cleanse his heart" and "preserve" himself from all anti-social behavior. Relate this to Mencius' contrary concern that bestowing favors willy-nilly shows an impulse to coerce the person into performing unseemly acts on the giver's behalf-to seize them disrespectfully, in his language. In the example from Wuyi guangchang (one of many in the Han-era writings) favor secures the dignity of the person. ${ }^{57}$

In real life during the early empires, we presume a range of complex rhetorical moves designed to negotiate between what, on the one hand, we might call colloquial talk about favor (as in the Liye document) and the set of ritual norms circumscribing ideal relationships, on the other. Yet the ideals were not all "gossamer", as it were; they had real-life consequences, we suggest. ${ }^{58}$ Significantly, once a person entered the world of ritual,

(Hong 1983, pp. 189-90); See (Hawkes 1985, pp. 212-13), modified slightly.

Hanshu 77.3262

56 (Changsha shi wenwu kaogusuo 2018), \#378, 2010CW1(3):199-1, p. 84.

57 We co-authors often avoid speaking of the self, knowing how much semantic baggage this drags into discussions (most of it dating to the European romantics); most, if not all early discussions in classical Chinese speak of the physical person (not the interior self). At the same time, we are mindful that English translation virtually demands this word at points. For deconstructions of the universal self, one could not do better than read (Rosemont 2015; Butler 2020).

58 Here we think of E. M. Forster's summation: "It is not all gossamer, what we have delighted in, it has become part of our armor, and we can gird it on, though there is no armor against fate." See (Forster 1955, p. 70). Or, as (Geuss 2008, p. 11), writes, aspirations and even illusions have considerable "motivational power." 
each person had inestimable authority (a presence that potentially, at least, commanded attention), and thus all authorities had perforce to be approached with reverence, as the Liji clearly states when describing how dignity imparts meaning and propels ritual courtesies:

Now, as we all know, ritual means abasing oneself and crediting others with honor and dignity. Now if even the most menial of people credit others with honor and dignity and necessarily have something of dignity in them, ${ }^{59}$ how much is this true with the wealthy and noble! 夫禮者, 自卑而尊人。雖負販者, 必有尊也。而況富貴乎! 60

As this passage clearly shows, the ritual classic need not describe the social hierarchy per se, given its readers' familiarity with that hierarchy. Why emphasize that dignitaries in office differ from those unfortunates who are doing the most menial work in society? Of course, societal hierarchy exists. The point of the passage does not lie there. The classic seeks to convey a far more subtle notion: that ritual invariably entails a show of esteem for the dignity of one's counterpart, even a relatively low-ranking counterpart. Another implication of the ambiguous phrase bi you zun ye (see above) is that the lowly may very well be better than the noble in esteeming others. Having less reason to be full of pride, they may welcome shows of mutual esteem all the more readily.

From the perspective of the upper echelon of the social order, many more texts emphasize that "even the Son of Heaven necessarily has those whom he esteems" 雖天 子必有尊也. As analyzed in the Bohu tong 白虎通, the Son of Heaven himself treats the Triply Aged (Sanlao 三老) and Quintuply Experienced (Wugeng 五更) ${ }^{61}$ as father and elder brother respectively, performing deference to them in the Bright Hall 明堂; he is also to treat his own tutors with extraordinary deference, ${ }^{62}$ For through deference the ruler inspires deference and obedience from others toward his own person. As the "Wei ren zhe tian" 為人者天 chapter of Chunqiu fanlu explains, ${ }^{63}$ the ruler's deference toward others is the precise means by which "instructive transformation" (jiao hua 教化) happens. By showing how much he esteems others, the Son of Heaven models and induces filial piety in his subjects. ${ }^{64}$ In the Classic of Filial Piety (Xiaojing 孝經), this performance of deference and its attending rituals is the means to establish order throughout the "four seas:"

For this reason, "even the Son of Heaven necessarily has those whom he esteems". This refers to his father. "He necessarily has those whom he places first". This refers to his elder brothers. He pays respect at the ancestral temple because he does not forget his parents. He cultivates himself and is cautious in action because he fears that he will humiliate those who come before him. By paying respect at the ancestral temple, the spirits manifest. ${ }^{65}$ 故雖天子, 必有尊也, 言

59 NB: While Zheng Xuan reads the text in a particular way to mean that even these profit-hungry people display ritual deference sometimes, the phrase is ambiguous and in other contexts implies that even the lowly are to be treated with dignity (a reading in line with Analects 12/2), so both meanings are translated here.

60 (Ruan 1815a, "Qu li", p.16b).

61 This refers to the man honored by the emperor as "Quintuply Experienced." See (Bodde 1975, pp. 372-79).

62 See "Xiang she" 鄉射 section, in (Chen 1994) (2017 rpt), juan 5, pp. 248-50. For an English translation, see (Som 1952, p. 477). The discussion of the Triply Aged and Quintuply Experienced here should be read alongside the discussion in juan 6 where they are among those whom "the king does not treat as subjects" 王者不臣. See Chapter 21, “Wang zhe bu chen", Bohu tong shuzheng, juan 7, p. 319; "Whom the King does not treat as subjects", Po Hu T'ung, p. 516.

63 The Chuniqiu fanlu is almost certainly a post-Han compilation that includes writings thought at the time to be "in the style" of Dong Zhongshu; the chapters focusing on the Five Phases theories have long been deemed to be of Six Dynasties date, since the genuine materials attributed to Dong never mention the Five Phases, only yin/yang. On this, see (Loewe 2011). That said, much of the Chunqiu fanlu recalls the work of He Xiu on the Gongyang.

64 (Su 1992) (2007 rpt.), juan 11, pp. 319-20. For translation, see (Queen and Major 2016, p. 365).

65 The classic work on the Xiaojing remains the Ph.D. dissertation by (Hsin-i Hsiao 1978). By Hsiao's account, the Xiaojing dates to the short-lived Qin dynasty (221-207 BCE), and probably is best characterized as a "Legalist text." While we no longer think in terms of rival schools, it certainly is a document designed to support imperial authority. 


\section{有父也；必有先也，言有兄也。宗廟致敬，不忘親也；修身慎行，恐辱先也。宗} 廟致敬, 鬼神著矣。6

In authoritative Han writings, all produced by and for one or another Western or Eastern Han court, it requires but a small step to move rhetorically from the requirements for visitation rituals to notions about the global order and the just realm under the ancestors watchful eyes (tianxia 天下), because the Son of Heaven's ritual performance of extreme deference supposedly affected the entire populace, most of whom, obviously enough, would never see or hear him in person. Yet by giving esteem to others he, in theory, secured his own legitimacy is the underlying logic said to inform the most solemn set of imperial rituals: the "suburban sacrifices" (jiao 郊). On the day of sacrifice, the Son of Heaven was to wear a "leather cap and listen to the sacrificial reports" so as to "show the people that he solemnly obeys the authorities above" (shi min yan shang 示民嚴上), high Heaven and the ancestors for whom he serves as humble functionary below. ${ }^{67}$ The result of this ritual performance was that the men and women of the suburbs "dared not dress in mourning clothes" on the days of this imperial sacrifice, it being so auspicious in strengthening the bonds between heaven and earth. Ideally, by the logic of legitimacy prevailing in the early empires, in ineluctable response "they [the imperial subjects] obeyed the authorities [the reigning emperor and his forebears] above without commands ever being issued" to them (fu ming er min ting shang 弗命而民聽上). ${ }^{68}$ In the words of the Han exegete Zheng Xuan 鄭玄, the people were "moved by the king's solemn obedience to the authority above" 化王嚴上, ${ }^{69}$ to requite him with the same obedience, obedience to authority being itself contagious, apparently. ${ }^{70}$

\section{Fear as the Pre-Condition for True Independence}

When we begin to speculate about why there is so much emphasis on the circle of fear in the early writings in classical Chinese, it can hardly be because the rulers were so despotic. Even the most despotic of them (Han Wudi, r. 141-87 BC, comes to mind) could do little to effect his will outside the major administrative seats of the empire, given the primitive transportation and communication facilities of the time. We speculate (but this is mere speculation, we realize, since the extant early sources do not explain what is obvious to them) that the situation in the early empires in China differed from that in the better-known classical Mediterranean. There were not two conditions (slave and free), but considerably more than twenty, when one counts the orders of honor, and then adds the various orders of those of servile status (temporary or permanent). Adding to the other complications, as below, we cite here no fewer than nine logically separate, and hierarchical sources of authority being in play at any given time and place:

1. hereditary background; family connections;

2. office-holding (rank therein);

3. orders of honor (jue, sometimes rewarding merit; sometimes to glorify the court and bind its subjects to the ruler and his inner circle);

4. aggregate wealth;

66 (Ruan 1815b, “Ganying”, 8.51b-52a). For a slightly different translation, see (Rosemont and Ames 2009, pp. 114-15).

67 (Ruan 1815a), “Jiao te sheng", 26.499a.

68 Ibid.

69 Ibid.

70 More mundane rituals in imperial times even made clear that the emperor would rise in the presence of the Chancellor 丞相 and descend from his chariot when meeting the latter on the road. See Hanshu 84.3414; Hou Hanshu 46.1565. For collected fragments related to this problem, see (Sun 1990, p. 66). 
5. impressive looks, bearing (decorum, charismatic presence), ${ }^{71}$ plus the ability to speak well; ${ }^{72}$

6. access to and acquisition of high cultural learning/book learning or special expertise (e.g., swordsmanship, astronomy). To command more than one type of expertise usually gave the person an "edge" in society-at-large, and certainly in career advancement, 73

7. age/seniority in a given situation;

8. guest and host relations (more on this below);

9. teacher-student relations.

The degree to which male/female distinctions (hierarchy \#10) assumed importance depended upon the other hierarchies in play, as can easily be seen from the case of dowager empress Deng Sui, who refused to yield power either to the duly capped emperor who had reached his majority or the senior male members of her natal family for a full fourteen years, simply because she could.

Even scanning the list, we moderns partake in the befuddlement that the dutiful person would have experienced in the early empires, if schooled by ritual to feel salutary dread. The standard histories increase our sense of befuddlement for three reasons: (1) the early Chinese courts did not hesitate to move people quite erratically up and down the administrative ranks; (2) nor were the administrators at those courts unaware of what we would call the "Peter principle": that capable people may nonetheless rise to positions far above their capabilities; and (3) whole families were dragged into court cases that might end in death, if only one of their members committed a crime deemed serious, for any reason. We cite two cases of reasons \#1 and \#2 below, since reason \#3 has been treated early and often in the secondary literature. ${ }^{74}$ Notably, both cases we adduce below were judged to be fair, by Sima Qian and Ban Gu, principal authors of the two standard histories for Western Han.

Feng Tang 馮唐 had lived to be over ninety sui, by the time Wudi's court considered him as a potential candidate for palace service. He was eventually nominated for a post as xianlang 賢郎 (“literally, courtier"), a post usually considered an entry-level advisory position. But long before that, during the reign of Wendi (r. 180-157 BC), Feng Tang had already served as courtier (lang 郎) in the imperial palace, from which post he had gone on to hold the very high-ranking posts of Cavalry Commandant and Chancellor of $\mathrm{Chu}$, more often awarded for meritorious service as the crown of one's career. In even the simplest encounter with Feng, anyone would have been perplexed as to how best to address him. Should be addressed by one of his former titles or as an ordinary man of the people, after being nominated to fill the xianlang's post? Most would have erred on the side of caution, we expect, less they offend a man and his family who might soon return to power.

Our second case drawn from the histories and exemplifying reason \#2 comes from Ban Gu's Hanshu biography of Zhu Bo 朱博, in late Western Han. In much of Zhu's biography, Ban Gu suggests that Zhu is an exceptionally talented bureaucrat who held the post of commandery governor with no problem whatsoever. However, Ban suggests also that the same qualities that made Zhu Bo such a success at the local level caused his prompt downfall as soon as he reached the elevated position of a high minister in the central court in Chang'an, under Han Chengdi (r. 33-7 BC). Zhu Bo's case certainly raises questions, the most important of which seems to be, What does Ban Gu mean when he says that Zhu

71 Dongguan Hanji 東觀漢記, juan 17.12, the liezhuan 周澤. See footnote 8 above for information. Hou Hanshu 79B.2579 says of him, “He rather lost any hope of becoming prime minister" 頗失宰相之望.

72 One of the reasons given for why Dong Zhongshu was never elevated to a higher rank is that he was not good in oral arguments. Having Gongsun Hong for an enemy is the second major reason that is listed.

73 Sloppy historians divide New Text from Old Text and then claim that "broad learning" was admired only in Old Text and in Eastern Han traditions; abundant counter-evidence exists.

74 A.F.P. Hulsewé's translation of Hanshu 23, the treatise on penal law and war, which discusses "collective responsibility" in some detail. See (Hulsewé 1955), Introduction. 
Bo "did not think overmuch about Dao and De", literally, the Way and its charismatic power (不思道德)? Is Ban Gu referring to Zhu Bo's disdain for the Classics or something else? ${ }^{75}$ Judging from the rest of the Hanshu, Ban Gu thinks that Zhu Bo, as bureaucrat, had never learned to care for the "Great Way" or "Great Enterprise" or "Great Duty", the "big picture" as we might call it. ${ }^{76}$ Certainly, Wang Chong 王充, author of Lunheng 論衡 (Discourses Weighed in the Balance) and student of Ban Gu's father, thought that care of the "big picture" is what distinguished real classicists commanding the utmost respect from pettifogging bureaucrats who never discerned the "spirit of the law" underlying its letter. ${ }^{77}$

\section{Slaved and Enslaved-Xunzi}

When it comes to thinking about salutary fear, no one is better to "think with" than Xunzi, the master of ritual, whose writings presume the true gentleman's acquisition of both a sense of freedom and a sense of dread. By Xunzi's account, it is thanks to his own circumspection (in both senses of the word, "seeing all sides" and "prudential action") that the noble man finds in himself a potential, whether "in activity or at rest", for developing a serene source of satisfaction, though he is ever-mindful of the hazards of social isolation and self-absorption. ${ }^{78}$

So long as the faculties located in the heart feel serene and at ease, then even colors and beauties that are less pleasing than usual suffice to feed the eye, and tones that are less pleasing than usual suffice to feed the ear. A diet of vegetables and a broth of greens suffices to nurture the mouth. Robes of coarse cloth and shoes of rough hemp suffice to support the bone structure. And a cramped room, reed blinds, a bed of dried straw, plus a stool and mat, suffice to support the bodily form. Thus, even without the finest things of the world [signifying high rank and status], a person can nurture his own sense of pleasure. And even without high rank, he can nurture his good name ... This we call "recognizing his own due weight and gravitas while putting others to use" ${ }^{79}$

Ideally, this lessened reliance on externalities for a sense of self-worth extends to the sociopolitical sphere, with Xunzi more than once exhorting people, as social beings, to avail themselves of every opportunity to participate as fully as possible in that alluring yet potentially dangerous sphere. Whereas "the petty man is enslaved by things", the noble man, by contrast, deploys every available resource he has to sustain himself in mental and emotional comfort. Meanwhile, the enticements of power and profit cannot disquiet him, for he has too strong a sense of his own honor and integrity ${ }^{80}$ He knows how to sustain himself in dire straits and besides, he has the courage to meet every exigency. ${ }^{81}$ Hence the couplets "Seeing the benefit in the mastery of his dispositions/Knowing his good name

75 “Truly, tools have their limits!" as we learn from Hanshu 83.3409.

76 Elsewhere, in her forthcoming Cambridge History chapter, Nylan expects to explain how pervasive this distinction is. The terms here are da dao 大 道, da ye 大業, da yi 大義/大意, etc.

77 On Lunheng: Wang Chong devotes no fewer than three full chapters to assessing the differences between classicists and functionaries: “Weighing Talents" (程材), “Measuring Understanding" (量知), and “Admitting Faults": (謝短). “Weighing Talents" responds to a prevalent criticism that functionaries are more useful and employable than classicists, instead showing that both have their strengths and weaknesses. "Measuring Understanding" stakes a stronger position, extolling the value of learning and arguing that classicists' superior scholarship (at least in theory) makes them superior officials. "Admitting Faults" then scrutinizes the roles of the classicists, arguing that, although "classicists are somewhat better than functionaries" (儒生頗愈文吏), many fail to live up to their ideals. Together, these three chapters provide one of the most detailed accounts of differences between classicists and functionaries, including their different abilities and tendencies, as well as perceived class distinctions between classicists and functionaries and their differing career paths. We co-authors acknowledge our debt to Nicolas Constantino, our colleague, for alerting us to the way these chapters build one upon the other.

78 H-Y 86/22/88: Such a man “values himself and makes other things work for him" (as below). H-Y is our abbreviation for Xunzi yinde 简子引得, Sinological Index Series Supplement no. 22 (Beiping: Harvard-Yenching Institute, 1950).

79 H-Y 86/22/85-86, only slightly modified from (Knoblock 1988-1994, 3 vols., p. 138).

80 For the first quote, see H-Y 4/2/20; for the second, H-Y 3/1/49; for the third, H-Y 63/17/26. Cf. H-Y 84/22/46 and H-Y 86/22/88. Several passages in the Zhuangzi speak to the importance of "treating things as things" and "refusing to be turned into a thing by [other] things [or entities]." $\mathrm{H}-\mathrm{Y}$ index 28/11/66; compare (Graham 1981, p. 121).

81 H-Y $2 / 1 / 32$. 
to be the real source of glory,/With hordes [of supporters], he may feel in harmony./But alone and in isolation, he still finds pleasures enough". ${ }^{82}$

And "since everybody who outwardly attaches great importance to other things is inwardly anxious", the noble man's relative indifference to some externals serves him well as he pursues his own pleasures in daily life, to the precise degree that he maintains and exemplifies the exquisite sense of courtesy towards all whom he meets. ${ }^{83}$ "This explains why the noble man, even when he has not yet gotten his rightful place in society, with all its perquisites, takes pleasure in what pervades his heart". ${ }^{84}$ (As Yang Xiong, the late Western Han master, succinctly put it two centuries later, the "sage takes pleasure in being a sage". $)^{85}$ From this, Xunzi concludes, one may say of such a man that he "is without an [extra] moment's anxiety and concern" (you 優). ${ }^{86}$ Anxiety and concern, after all, generally stem from nothing more than deep-seated fears about a future deprivation of sources of pleasure. And the noble man is clear on this: there can be no real "poverty and misery where true humaneness is found, and no [long-lasting] riches and honor where it is absent ${ }^{\prime \prime}{ }^{87}$ For all of these reasons, the determination to acquire goodness and grace (de 德) holds out the fairest hope of obtaining success ( $d e$ 得) in life, ${ }^{88}$ chiefly because the ordinary desires for conventional goods depend too much on others' arrangements. That said, while attaining a degree of admirable autonomy, "not divided against oneself", even in the face of disgrace or death, the noble man exerts a remarkable mastery over his outward physical form, trained as it has been to impart an air of grace and ease that colors all his chosen activities. $^{89}$

Behind Xunzi's various descriptions of the noble man who can operate well in a dangerous world, due to his training in ritual, there lies his profound recognition of the most basic and shared aspect of the general human condition: plainly put, so far as we know, people in all eras in all status roles have longed to be accorded a small measure of dignity within a community of dignified beings. As neuroscientists, philosophers, and humanists all now agree, a rich social environment for humans requires the development of human emotional and imaginative faculties, most importantly, the ability to imagine others as having intentional states comparable to our own and the allied ability to imagine ourselves as having intentional states different from our current set of predilections. Human beings need and desire, in other words, that "face" be acknowledged by real members of real communities, and this acknowledgment people tend to value over fictional autonomy. One philosopher of the emotions put it this way: "Imagine that each of us lives at the center of a set of concentric circles, the nearest being our own self, the furthest being the entire universe of living creatures. The task of our moral development is to move the circles progressively closer to the center, so that we regard our parents and children like ourselves, our other relatives like our parents, and strangers like our relatives". ${ }^{90}$ That civility in society - so often expressed in the sources in terms of fears of offendingvirtually guarantees a humane and dignified extension of physical and psychic safety leads us inexorably back to early teachings often labeled as Confucian, but which were actually far more pervasive during the early empires: "If it is really possible to govern countries by

82 H-Y $12 / 4 / 71$.

83 H-Y 86/22/79. Cf. H-Y 4/2/19.

84 H-Y 105/29/32. The passage continues, "and once he gets [his rightful place], then he also takes pleasure in his administration of affairs." H-Y 86/22/87: "This is why he can be without the finest examples of the myriad sorts and still be able to be sufficiently nourished with respect to pleasure."

85 Yang Xiong, Fayan 3/3, after (Nylan 2013).

86 H-Y 105/29/32.

87 H-Y 90/23/84.

88 This is a standard pun in late Zhanguo and Han texts.

89 H-Y 80/21/47.

90 (Ben-Ze'ev 2000, p. 260) 
ritual and yielding, there is no more to be said. And if it is really not possible, then of what use is ritual?" 91

A second line from the Analects adds to this same picture, Analects 12/2, where the Master says, "Behave when away from home as if in the presence of an important guest. Deal with the common people as if you were officiating at a solemn sacrifice ${ }^{\prime \prime} .{ }^{92}$ The passage enjoins members of the governing elite to see in their minds' eyes what words and gestures they might deem humiliating, demeaning, and condescending, and then avoid using those words and gestures with any others. In essence, then, they were instructed to treat others with the exquisite courtesy willingly vouchsafed to recognized dignitaries. This treatment first placed they themselves in the customary honorable role of the host who owes and wants to be hospitable to others. For the good host not only meets, but also anticipates the needs of the guests, especially if important guests come to visit. And the good host continually asks guests what they need and like, rather than presuming what they merit. It required members of the governing elite to regard those actually in their power as if they were a higher power, without conceding to worldly powers that power to harm themselves or others.

What such early texts do not emphasize-it being perhaps too obvious for authors of the time to stress - is the breadth of the circles of fear, encompassing as they did everyone in the mourning circle who was therefore liable to collective punishment, bureaucratic subordinates and the family's clients and household retainers, and often more casual acquaintances as well. Recall how sudden where many of the reversals of fortune in early times, with many of these accompanied by a falling away of once-firm allies. ${ }^{93}$ Add to this the multiple proscriptions against court officials carried out under all Western and Eastern Han courts, if most prodigiously during the last half-century of Eastern Han, ${ }^{94}$ and it becomes mere child's play to envision just how huge the circle of palpable fear must have been for potential and actual candidates for office and their families, such that a single small ritual lapse expressing a discourtesy, like that unwittingly or too casually incurred by Ban $\mathrm{Gu}$ or his servant, could elicit the harshest forms of punishment, not only exile from the court but also excruciating and humiliating forms of torture and death. Such dreadful potentials would have proved to many to be no small spur to undertaking serious schooling in ritual speech and ritual gestures, regardless of ethical commitments.

\section{Conclusions}

Describing ritual and religion in early China, modern scholars tend to focus on a few dramatic episodes, for example, Qin Shihuang or Han Wudi worshipping at the sacred Mount Tai. These, however, prompt ruminations on individual, top-down power relations that can be likened to standard EuroAmerican notions, whereas close examination of the Classics, standard histories, and masterworks from early China supplies remarkably different scenarios. ${ }^{95}$ Modern scholars of ritual have moreover been apt to focus on ritual's elevating transformative effects on the psyche and "inner cultivation", as explicated in "universal" ritual theories. This essay, by contrast, has tried to reconstruct for readers a culture of fear in early China that was pervasive in theory and practice, and which supposedly informed the behavior of all cultivated people, with departures from the model not only noted but also excoriated. What, in theory, salutary fear did for oneself and others was impart a welcome measure a dignity to all.

91 Analects 4/13.

92 Analects 12/2, when the disciple Ran Rong asked about goodness.

93 This topic is discussed frequently in connection with Sima Qian in (Durrant et al. 2016), as well as throughout The Cambridge of History, Vol. 1, 1, The Ch'in and Han empires, 221 B.C.-A.D. 220.

94 The classic work on the proscriptions is that by (de Crespigny 1975). When (Levine 2008, p. 38), that the Han proscriptions affected some 200 scholar-officials, this clever man has failed to understand the much wider circles the proscription affected; he thinks in terms of modern individualism.

95 Like (Boyarin and Barton 2016; also Project Muse), we co-authors believe that what we call "religion" prior to religious Daoism and Buddhism is mainly a set of prohibitions. For Mount Tai, the classic source remains (Chavannes 1910). 
Perhaps a few final words about dignity are in order here, and because no one essay has sufficient space to stimulate thoughts spinning off in too many directions, we end simply by registering two main ideas here about what the early texts in classical Chinese seem to be doing and might do for us today, if we would heed them. The first is that the proper and most effective way to secure the safety of the body and the body politic must be premised on hard lessons learnt, via the continual reiteration of historical and pseudo-historical events, about the wisdom of not effacing the strong desires of fellow human beings to be recognized as such, ${ }^{96}$ which lesson ideally leads to the development of a possibly unique human capacity truly worth celebrating. In the Chinese way of speaking, members of the governing elite were to learn how to "become humans", meaning, to become dignified (and so impressive models) because they had learnt how to grant dignity to others. As the classical texts repeatedly unscored, realistically speaking, only by doing the work of nurturing others could those in power hope to live secure in their own pleasures, this being the only condition which did not threaten to make them or others into virtual slaves. What this early lesson did, however, is remove them quietly but firmly away from the "main aspects of modern identity-liberty, autonomy, ... the subject's self-positioning or rational self-determination",, 97 such that Foucault and, indeed, all modern notions of power become inapplicable and irrelevant to the propositions the classic Chinese texts seek to persuade readers of.

Second, a wide range of texts adopts the metaphor of a "barrier" or "dike" (fang 坊) for ritual. This metaphor is found not only most famously in the Rites Record (Liji 禮記) classic, ${ }^{98}$ but also in other classical-era texts, including Wang Chong's Lunheng. ${ }^{99}$ Wang's use of the metaphor is especially salient in the present context inasmuch as he highlights the way that ritual norms are manifestations of our "reverence for what came before" 尊始. The salutary fear and deference expressed in bowing (bai 拜) and asking ( $y e$ 謁) are concrete instantiations of the larger fear and awe in the face of the unseen beginnings. In his essay, Wang mocks Han Feizi for trying to convert every consideration into a cost-benefit analysis. Wang wryly probes, Would Han Feizi willingly appear before his father or a ruler without the proper garb and demeanor? This primordial reverence (zhong ben zun shi 重本尊始) is "the old dike" (jiu fang 舊防) that prevents the worst of abuses. In a similar vein, the scholar Zeng Yi 曾亦 laments how Chinese since the late Qing have criticized this kind of bowing as "the height of inequality". ${ }^{100}$ Zeng considers the key insight of the old ritual texts to be "lowering oneself while honoring others" 自卑而尊人. Indeed, he underscores how the ubiquitous practice of "bowing", the physical performance of "debasing oneself" even before juniors or inferiors, buttressed human dignity for all. Salutary fear, we suspect, was the emotional underpinning of this ancient ritual barrier.

Author Contributions: In this essay, both M.N. and T.W. are true co-authors, in that each contributed half of the ideas and sources on which this paper is based. They are therefore listed in alphabetical order. This work builds upon their earlier joint work entitled "A Brief History of Daring" and "The Dowager Empress Deng Sui: a study of legal, cosmological, and gender theories in Eastern Han" (both scheduled for publication in 2021). All authors have read and agreed to the published version of the manuscript

Funding: This research received no external funding.

Institutional Review Board Statement: "Not applicable" for studies not involving living humans or animals.

96 Analects 2/18. We take zai qi zhong 在其中 in the sense that Waley takes it in his "Additional Notes": "It is used of results that occur incidentally without being the main object of a certain course of action." Moral learning should be autotelic (an end unto itself), the early Confucians tell us.

97 (Canto-Sperber 2008, p. 45).

98 One might consult Jeffrey K. Riegel, “The Four 'Tzu ssu' Chapters of the Li Chi: an analysis and translation of the (Riegel 1978), which shows the entire "Fang ji" 坊記 (in pinyin romanization) chapter circling around this metaphor.

99 See Lunheng, “Fei Han” 非韓 chapter: 儒者在世, 禮義之舊防也. (Huang 1990, p. 423).

100 (Zeng 2019, p. 4). Nylan and Wilson would like to thank the two anonymous readers for their careful reports, from which we have profited. 
Informed Consent Statement: Not applicable.

Data Availability Statement: Data available in a publicly accessible repository .

Conflicts of Interest: The authors declare no conflict of interest.

\section{References}

Barton, Carlin A. 2001. Roman Honor: The Fire in the Bones. Berkeley: University of California Press.

Ben-Ze'ev, Aaron. 2000. The Subtlety of the Emotions. Cambridge: MIT Press.

Bodde, Derk. 1975. Festivals in Classical China: New Year and Other Annual Observances during the Han Dynasty, 206 B.C.-A.D. 220. Princeton: Princeton University Press.

Boyarin, Daniel, and Carlin Barton. 2016. Imagine No Religion; How Modern Abstractions Hide Ancient Realities. New York: Fordham University Press.

Branner, David, and Feng Li, eds. 2018. Writing and Literacy in Early China. Seattle: University of Washington Press.

Butler, Judith. 2020. The Force of Non-Violence: An Ethico-Political Bind. London: Verso Books.

Canto-Sperber, Monique. 2008. Moral Disquiet and Human Life. Translated by Sylvia Pavell. Princeton: Princeton University Press.

Changsha shi wenwu kaogusuo 長沙市文物考古所. 2018. Changsha Wuyi guangchang Dong Han jiandu 長沙五一廣場東漢簡牘. Shanghai: Zhongxi shuju, vol. 1.

Chavannes, Édouard. 1910. Le T'ai Chan: Essai de monographie d'un culte Chinois. Paris: E. Leroux.

Chen, Li 陳立. 1994. Bohu tong shuzheng 白虎通疏證. Beijing: Zhonghua shuju.

Chen, Shou 陳壽. 1959. Sanguo zhi 三國志. Beijing: Zhonghua shuju.

Chen, Wei, ed. 2012. Liye Qinjian jiaoshi 里耶秦簡校釋. Wuhan: Wuhan daxue chubanshe, vol. 1.

Couvreur, Séraphin. 1928. Cérémonial: Texte chinois et traduction. Sien Xian: Imprint de la Mission catholique.

de Crespigny, Rafe. 1975. Political Protest in Imperial China: The Great Proscription of Later Han, 167-184. Canberra: Department of Far Eastern History.

de Crespigny, Rafe. 2007. A Biographical Dictionary of Later Han to the Three Kingdoms (23-220 AD). Leiden: Brill.

de Harlez, Charles. 1890. I-li: Ceremonial de la Chine Antique. Paris: J. Maissonneuve.

Dirlik, Arif. 2008. Race Talk, Race, and Contemporary Racism. PMLA 123: 1363-79. [CrossRef]

Dirlik, Arif. 2011. Guoxue/National Learning in the Age of Global Modernity. China Perspectives 85: 4-13. [CrossRef]

Durrant, Stephen, Li Waiyee, and Hans van Ess. 2016. The Letter to Ren An and Sima Qian's Legacy. Washington, DC: University of Washington Press.

Durrrant, Stephen, Wai-yee Li, and David Schaberg. 2016. Zuo Tradition: Commentary on the 'Spring and Autumn Annals'. Seattle: University of Washington Press.

Fan, Ye 范曄. 1965. Hou Hanshu. Beijing: Zhonghua shuju.

Forster. 1955. A Note on the Way. In Abinger Harvest. New York: Meridian Books.

Gentz, Joachim. 2020. Chinese he in Many Keys, Harmonized in Europe. In Keywords in Chinese Culture. Edited by Li Wai-yee and Yuri Pines. Hong Kong: Chinese University of Hong Kong.

Geuss, Raymond. 2008. Philosophy and Real Politics. Princeton: Princeton University.

Angus Charles Graham, trans. 1981, Chuang Tzu: The Inner Chapters. London: George Allen \& Unwin.

$\mathrm{Gu}$, Jiegang 顧頡剛, and Qiyu Liu 劉起釬. 2005. Shangshu jiaoshi yilun 尚書校釋譯論. Beijing: Zhonghua shuju.

David Hawkes, trans. 1985, Songs of the South: An Ancient Chinese Anthology of Poems by Qu Yuan and Other Poets. London: Penguin Classics.

Hightower, James. 1952. Han Shih Wai Chuan: Han Ying's Illustrations of the Didactic Application of the Classic of Songs. Cambridge: Harvard University Press.

Hong, Xingzu 洪興祖. 1983. Chuci buzhu 楚辭補注. Beijing: Zhonghua shuju.

Hou, Xudong 侯旭東. 2015. “Zhongguo gudai zhuanzhizhuyi shuo de zhishi kaogu” 中國古代專制主義説的知識考古. In Jinguan zhonggu shi 近觀中古史. Shanghai: Zhongxi shuju.

Hsin-i Hsiao, Harry. 1978. Filial Piety in Ancient China: A Study of the Hsiao-ching. Ph.D. dissertation, Harvard University, Cambridge, MA, USA.

Huang, Hui 黃睴. 1990. Lunheng jiaoshi 論衡校釋. Beijing: Zhonghua shuju.

Hulsewé, Anthony François Paulus. 1955. Remnants of Han Law. Leiden: Brill.

Knoblock, John. 1988-1994. Xunzi: A Translation and Study of the Complete Works. Stanford: Stanford University Press, vol. 3.

Lau, Din Cheuk. 1970. Mencius, Translated with an Introduction. Harmondsworth: Penguin.

Lendon, Jon. 1997. Empire of Honour: The Art of Government in the Roman World. Oxford: Clarendon Press.

Levine, Ari D. 2008. Divided by a Common Language: Factional Conflict in Late Northern Song China. Honolulu: University of Hawaii Press.

Li, Wai-yee, and Yuri Pines, eds. 2020. Filial Piety as an Emotion in Late Imperial China. In Keywords in Chinese Culture. Hong Kong: Chinese University of Hong Kong.

Loewe, Michael. 2010. Social Distinctions, Groups and Privileges. In China's Early Empires. Edited by Michael Nylan and Michael Loewe. Cambridge: Cambridge University Press.

Loewe, Michael. 2011. Dong Zhongshu: A “Confucian" heritage and the Chunqiu fanlu. Leiden: Brill. 
Mantel, Hillary. 2020. The Mirror \& the Light. London: HarperCollins Publishers.

Montesquieu. 1989. The Spirit of the Laws. Translated by Anne M. Cohler, Basia C. Miller, and Harold S. Stone. Cambridge: Cambridge University Press.

Nussbaum. 2018. The Monarchy of Fear: A Philosopher Looks at our Political Crisis. Oxford: Oxford University Press.

Nylan, trans. 2013, Exemplary Figures: A Complete Translation of Yang Xiong's Fayan. Seattle: University of Washington Press.

Queen, Sarah A., and John S. Major, eds. 2016. Chapter 41, "Heaven, the Maker of Humankind". In Luxuriant Gems of the Spring and Autumn. New York: Columbia University Press.

Richter, Antje. 2013. Letters and Epistolary Culture in Early Medieval China. Seattle: University of Washington Press.

Richter, Antje, ed. 2015a. A History of Chinese Letters and Epistolary Culture. Brill: Leiden.

Richter, Antje, ed. 2015b. Private Letter Manuscripts from Early Imperial China. In A History of Chinese Letters and Epistolary Culture. Leiden: Brill.

Riegel, Jeffery K. 1978. The Four "Tzu Ssu" Chapters of the Li Chi: An Analysis and Translation of the Faug Chi, Chung Yung, Piao Chi, and Tzu i. Ph.D. dissertation, Stanford University, Stanford, CA, USA.

Rosemont, Henry, Jr. 2015. Against Individualism: A Confucian Rethinking of the Foundations of Morality, Politics, Family, and Religion. Lanham: Lexington Books.

Rosemont, Henry, Jr., and Roger T. Ames. 2009. The Classic of Family Reverence: A Philosophical Translation of the Xiaojing. Honolulu: University of Hawai'i Press.

Ruan, Yuan, ed. 1815a. Liji zhushu 禮記注疏 (“Qu li, shang”曲禮上, “Jiao te sheng” 郊特牲 chapters). In [Chongkan Songben] Shisan jing $z h u s h u$ 重刊宋本十三經注疏. Preface dated 1815; 1965 rpt. Taipei: Yiwen yinshuguan.

Ruan, Yuan, ed. 1815b. Xiaojing zhushu 8: 51-52 (“Ganying zhang” 感應 section). In [Chongkan Songben] Shisan jing zhushu 重刊宋本十 三經注疏. Preface dated 1815; 1965 rpt. Taipei: Yiwen yinshuguan.

Sanderovitch, Sharon. 2017. Presence and Praise: Writing the Imperial Body in Han China. Ph.D. dissertation, University of California, Berkeley, CA, USA.

Som, Tjan Tjoe. 1952. District Archery. In Po Hu T'ung: The Comprehensive Discussions in the White Tiger Hall [hereafter Po Hu T'ung]. Leiden: Brill, vol. 2.

Steele, John. 1917. The I-li, or Book of Etiquette and Ceremonial. London: Probsthain \& Co.

$\mathrm{Su}, \mathrm{Yu}$ 蘇輿, ed. 1992. Chapter 41, “Wei ren zhe tian” 為人者天. In Chunqiu fanlu yizheng 春秋繁露義證. Beijing: Zhonghua shuju.

Sun, Xingyan 孫星衍. 1990. Hanguan liuzhong 漢官六種. Beijing: Zhonghua shuju.

Wang, Hui 王輝, ed. 2008. Yili zhushu 儀禮注疏. Shanghai: Shanghai guji.

Wilson, Trenton. 2021. Empire of Luck. Ph.D. thesis, University of California, Berkeley, CA, USA.

Wu, Wenling. 2017. Liye Qinjian 'Xin yu Lübo shu' shixi 里耶秦簡《欣與呂柏書》試析. Edited by Defang Zhang 張德芳. In Gansu sheng di san jie jianduxue guoji xueshu yantaohui lunwenji 甘肅省第三屆簡牘學國際學術研討會論文集. Shanghai: Shanghai cishu chubanshe.

Yang, Tianyu. 1994. Gifts, Favors, and Banquets: The Art of Social Relationships in China. Ithaca: Cornell University Press.

Yang, Tianyu 楊天宇. 2007. Zheng Xuan san Li zhu yanjiu 鄭玄三禮注研究. Tianjin: Tianjin Renmin chubanshe.

Zeng, Yi. 2019. Bai li yanjiu 拜禮研究. Shanghai: Shanghai guji chubanshe.

Zhang, Lie 張烈. 2005. Liang Hanji 兩漢紀. Berjing: Zhonghua shuju, vol. 1.

Zheng, Yifan. 2020. University of California-Berkeley, Berkeley, CA, USA. Personal communication. 